\title{
Urban Tanzîmât and Corrupting Property: Women as Petitioners of Honor in Nineteenth-Century Istanbul
}

\author{
Eda Güçlü \\ PhD Candidate, History Department, Central European University \\ eda.guclu@gmail.com
}

\begin{abstract}
This article examines the relations between tanzîmât and corruption within the context of urban renewal projects in nineteenth-century Istanbul. It takes corruption as a critical locus of analysis in order to understand notions of justice and morality that historical actors fashioned in the social production of urban tanzîmât and property relations. It reveals that a theme of honor was central to both state institutions and real estate owners with regard to the positions that they took in property conflicts that emerged as a result of planning activities in the city. This study argues that honor was not only a moral but also an economic theme that revolved around the question of locational values in this intense period of spatial restructuring.
\end{abstract}

\section{Keywords}

urban tanzîmât - Istanbul - capitalist modernity - city planning - property corruption - honor - morality - social justice - petitioning

\footnotetext{
* I thank Tolga Esmer and Sinan Çetin for their insightful comments on the drafts of this article. I also thank Koç University Research Center for Anatolian Civilizations in Istanbul for supporting me through a fellowship during the writing process of this research.

** Unless otherwise noted, all translations are my own.
} 


\section{Introduction}

For many Ottoman reformers of the nineteenth century, Istanbul was "unique in the world." It was "such a beautiful city" endowed with "diverse natural charms" and located in an "advantageous position."2 Tanzîmât men were sincerely proud of the city, especially of its potential, if not its reality. But they seem to have been quite apologetic when they expressed their thoughts and feelings because all the "uniqueness" of the city was being wasted by, before anything else, fires. It was a wooden city. Its streets were "unseemly," "messy," "irregular," and "crooked." ${ }^{3}$ And, as such, they were a defect in the pride of progressivist reformers. The city resembled "a big village" 4 rather than an imperial capital that was supposed to be the true display of the level of "order and civilization" of a state. ${ }^{5}$ It was lagging behind Western capitals. It was a "contemporary" city of the "non-contemporaneous," 6 "marginalized" by the peremptory examples of Paris, Vienna, and London in terms of both time and space. ${ }^{7}$ In other words, the city was not living in the modern "now." The apologetic manner of many tanzîmât reformers was predicated on this perceived "time-lag" between Ottoman and European capitals. ${ }^{8}$ Urban reforms were necessary to turn Istanbul into a "modern" capital and place it in the same present as Western cities. Reformers of the tanzîmât period sought the cure in the creation of a uniform urban space with wide and straight streets and the conversion of the wooden texture of the capital into masonry. Fires that were deemed

1 "dünyâda eşi olmayan": Başbakanlık Osmanlı Arşivi [Prime Ministerial Ottoman Archive] (hereafter BOA), İrade-i Dahiliye (hereafter i..DH ), 572/39882.

2 "İstanbul gibi güzel bir beldenin"; "letâfet-i mütenevvi-i tab^îiye"; "muhassenât-ı mevki ‘ye": BOA, İ.DH, 572/39882.

3 "münâsebetsiz"; "karmakarışık"; "gayr-i muntazam": BOA, i..DH, 572/39882; "eğrî büğgü": BOA, İrade-i Meclis-i Vâlâ (hereafter ì.MVL), 550/24667.

4 "İstanbul gibi büyük bir köyden başka sûrette tavsîfi mümkün olmayan bir memleket": Osman Nuri Ergin, Mecelle-i Umûr-ı Belediyye, vol. 3 (Istanbul: İstanbul Büyükşehir Belediyesi Kültür İşleri Daire Başkanlığı Yayınları, 1995), 1432.

5 An official memorandum dated 1856, "intizâm ve medeniyet": Ergin, Mecelle-i Umûr-ı Belediyye vol. 3, 1275-7.

6 Ernst Bloch, Heritage of Our Times (Cambridge: Polity Press, 1991); Harry Harootunian, History's Disquiet: Modernity, Cultural Practice, and the Question of Everyday Life (New York: Columbia University Press, 200o); Harry Harootunian, "Some Thoughts on Comparability and the Space-Time Problem," Boundary 2 32, no. 2 (Summer 2005): 23-52.

7 Deborah L. Parsons, "Paris is not Rome, or Madrid: Locating the City of Modernity," Critical Quarterly 44, no. 2 (July 2002): 20-21.

8 Ritika Prasad, “'Time-Sense': Railways and Temporality in Colonial India," Modern Asian Studies 47, no. 4 (July 2013): $125^{2}$. 
to have drastically affected "the growth and progress of civilization and prosperity" were also opportunities to initiate urban reforms. ${ }^{9}$ After all, being in tune with the "delicate times" was a civilizational necessity. ${ }^{10}$

In the discursive imaginations of tanzîmât men, the city was subjected to a new kind of abstraction that required a "break with the past."11 Urban space was exposed to a "technical rationality" that aimed to create order by geometry. ${ }^{12}$ The streets, in particular, became the object of capitalist modernity. The Ottoman reformers' concern with streets runs like a red line through archival sources. Their desire to create a regular and standard urban space was not only a reflection of a rational administration but also of a process where streets were increasingly commodified. In other words, the construction of wide and straight streets was not only a matter of new urban aesthetics but also a process of value creation in the built environment. Giving a new order to the city was also an attempt to change relational values of urban property.

However, urban reforms were difficult enough to materialize as they required an extensive spatio-temporal restructuring and planning within the boundaries of which there was a myriad of historical actors with different narrative, moral, and legal strategies. The government needed to produce a collective fiction of urban rent in order to moderate competing visions of urban tanzîmât and convince people of the benefits that redevelopment plans would bring. ${ }^{13}$ Such a fiction was crucial to justify expropriation and the relocation of many parcels for the regularization of streets. The government conceptualized expropriation as a "sacrifice" on behalf of property owners, which they

9 "medeniyet ve ma'mûriyetin tezâyüd ve terakkisi": BoA, İrade-i Meclis-i Mahsus (hereafter I.MMS), 31/1287.

10 "vakt-i nâzik": Ergin Mecelle-i Umûr-ı Belediyye vol. 3, 1270.

11 Harootunian, "Some Thoughts on Comparability and the Space-Time Problem," 32.

12 Sylvain Malfroy, "The Modern Completion of the Nineteenth-Century Fabric Based on the Grid and Blocks," in Rethinking the XIXth Century City, ed. Attilio Petruccioli (Cambridge, Massachusetts, The Aga Khan Program for Islamic Architecture, 1998), 142.

13 For the phrase "collective fiction of urban rent," I was inspired by Duygu Parmaksızoğlu. She uses the expression "rant ortaklığı kurgusu" in her article on contemporary urban redevelopment of Fikirtepe in Istanbul. In the English version of the article, she translates it as "the stakeholder scheme." By playing with the words, I preferred to use it as collective fiction of urban rent. Duygu Parmaksızoğlu, "Evden Emlağa Fikirtepe: Rant ve Spekülasyon Ekseninde Kentsel Dönüşüm," 28 September 2014, http://www .jadaliyya.com/pages/index/19382/evden-emlaga-fikirtepe_rant-ve-spekulasyon-eksenin, [the English version: "From Home to Real Estate: Urban Redevelopment on the Axis of Speculation in Istanbul,” 6 October 2014, http://www.jadaliyya.com/pages/index/19508/ from-home-to-real-estate_urban-redevelopment-on-th]. 
were required to make in return for betterment values and the public good. "Şeref," literarily meaning "honor, pride, distinction," was a key concept that signified this redistributive logic within the relational and relative values of urban property. The Turkish conjunction, emlâk-ı kesb-i şeref, referred to the expected increase in real estate values after the reorganization. According to the government, everybody was to benefit from urban reforms through the increasing şeref of their property. This expected increase in value was what justified expropriation in the eyes of the state but the reality of the planning process on the ground was not as straightforward as this official logic. As a matter of fact, the adjustment of betterment values to the "sacrifices" was itself a contingent and contested process as there were competing definitions of "public good." What was "good" for the more effective circulation of goods and people through the creation of wide and straight streets on a grid system was a matter of social as well as economic scaling that usually discredited tensions between morality and capitalist modernity.

Even though the fiction of urban rent was clean and clear-cut as a discourse, somber complexities were lurking behind urban tanzîmât. One of the most pressing problems was corruption. Urban reforms impacted all those fortunes, large or small, that would pass hands during the reorganization of the capital city. People, whether official or private, rich or poor, man or woman, Muslim or non-Muslim, ordinary or otherwise, were all participants in the imaginations of the city's future. Some acted upon new opportunities that urban reforms presented for personal gain. Among other things, urban tanzîmât was also an occasion to be "corrupt." This period was conducive towards creating space for corruption as much as it created a collective fiction of urban rent. This opportunity was material and fashioned itself as a tangible proof of the merits of tanzîmât reform in urban space.

However, the topic of corruption, as the somber side of urban tanzîmât, has received almost no systematic attention as a historical subject. At best, it has been acknowledged as something happening in the background but we still tend to think of it ahistorically for it feels so "ordinary" and "widespread" since time immemorial. ${ }^{14}$ The structural relation between urban planning and corruption has usually been overlooked to such an extent that corruption has been reduced to the same old story that always occurs as a part of a ubiquitous backdrop..$^{15}$ In this article, I argue against this common assumption that offers

\footnotetext{
14 Cengiz Kırlı, "Yolsuzluğun İcadı: 1840 Ceza Kanunu, İktidar ve Bürokrasi," Tarih ve Toplum Yeni Yaklaşımlar, no. 3 (Fall 2006): 45 .

15 Zeynep Çelik, The Remaking of Istanbul: Portrait of an Ottoman City in the Nineteenth Century (Berkeley: University of California Press, 1993); Pierre Pinon, "The Parcelled
} 
no historical substance to corruption. Instead, I take it as a critical locus of analysis in order to understand notions of justice and morality that historical actors invoked and fashioned in the social production of urban tanzîmât and property relations in nineteenth-century Istanbul. Its ordinary and daily manifestations reflect not only the basic commodified margins of negotiations in a transforming rent market but also relations between justice, civil officialdom, and state legitimacy.

In order to historicize corruption in terms of city planning, I focus on the reorganization activities in intra muros Istanbul following the fires of Mercan and Hocapaşa in 1865. The fire of Mercan happened a couple of months before the Hocapaşa fire and its scale was much smaller. The area eventually became a part of the larger planning scheme that the government envisioned after the Hocapaşa fire, one of the biggest urban disasters of the century. It started in the Hocapaşa district of Istanbul near Sirkeci train station and destroyed a huge area. Around 2,751 buildings in 27 neighborhoods were reduced to ashes and approximately 1,200 families lost their houses. ${ }^{16}$ All the dwellers of and businesses in these neighborhoods were to be given new plots but often in new locations that usually generated vociferous debate, protest, and intrigue.

To be sure, imperial visions of urban renewal and the contentious relocation plans underpinning them were contested by property holders on various grounds. My main purpose is to illustrate how, by whom, and through which control mechanisms property disputes resulting from urban reforms were settled in this intense period of spatial restructuring. I show that a theme of

City: Istanbul in the 19th Century," in Rethinking the XIXth Century City, ed. Attilio Petruccioli (Cambridge, Massachusetts, The Aga Khan Program for Islamic Architecture, 1998), 45-64; Cem Behar, A Neighborhood in Ottoman Istanbul: Fruit Vendors and Civil Servant in the Kasap Ilyas Mahalle (Albany: State University of New York Press, 2003); Maurice Cerasi, The Istanbul Divanyolu (Istanbul: Orient-Institut, 2004); Murat Gül, The Emergence of Modern Istanbul: Transformation and Modernization of a City (London: IB Tauris, 2009); Murat Gül and Richard Lamb, "Mapping, Regularizing, and Modernizing Ottoman Istanbul: Aspects of the Genesis of the 1839 Development Policy," Urban History 31, no. 3 (2004): 420-36; Steven Rosenthal, "Foreigners and Municipal Reform in Istanbul: 1855-1865," International Journal of Middle East Studies 11, no. 2 (1980): 227-45; Ayşe Derin Öncel, Apartman: Galata'da Yeni bir Konut Tipi (Istanbul: Kitapyayınevi, 2010); Lorans Izabel Baruh, “The Transformation of the 'Modern' Axis of Nineteenth-Century Istanbul: Property, Investments and Elites from Taksim Square to Sirkeci Station" (PhD Dissertation, Boğaziçi University, 2009).

16 воA, I.DH, 542/37739. Another document places the total number of the burnt-down buildings at 2879: BOA, I.DH, 540/37561; According to the official newspaper, the total number is 2751: Takvîm-i Vekâyic, 23 November 1866. 
honor was central to both state institutions and property owners with regard to the positions that they took in such conflicts. For property owners, the concept of honor was not only a rhetorical tool to enforce their understanding of justice and morality against corruption but also a collective leverage to negotiate the value of their property in a changing rent market. Alongside the concept of şeref, words like nâmûs (honor), haysiyet (dignity, honor, value), i'tibâr (esteem, honor, nominal value), and istikâmet (uprightness, integrity) were some of the most common terms that people quite frequently employed within an ideological economy of planning. The way in which property holders associated honor with space and value not only reveals the rhetorical interplay between the notions of morality and justice but also compels us to think about the question of property value as a web of social relations imbued with moral values. Seen in a continuum, the correlation between the themes of honor and corruption are so palpable that they could be evoked interchangeably. Corruption may also be seen as an operational element in many property conflicts, cutting through the legal and social ambiguities, yet producing another web of relations that gave the locational value its social character.

Likewise, for state institutions such as municipal organizations and special commissions, a discourse of honor was concomitantly a moral check on corruption in fashioning institutional ideologies, as well as a means of justifying expropriation and changing locational values. During the nineteenth century, the city was subjected to the experimental logics of tanzîmât in municipal reform and witnessed the creation of new administrative institutions that usually operated alongside the old ones. Institutions like the Şehremâneti, a municipal body modeled after the French Prefecture and the Municipality of the Sixth District (Altıncı Dâiire-i Beledîye), among others, were to centralize and restructure the city administration with an ideology of services. During this intense period of institutional change, urban government increasingly came to mean services (hizmet) distributed centrally in return for taxes ${ }^{17}$ while economic needs of the state brought about new conceptions of urban property together with the idea of taxing real estate which, until then, was exempt from taxation. ${ }^{18}$ As in the case of expropriation, it is also possible to find the con-

\footnotetext{
17 Tarkan Oktay, Şehremaneti, Osmanlida Büyükşehir Belediye Yönetimi (İstanbul: Yeditepe Yayınevi, 2011), XXIV.

18 The first attempt to tax real estate in Istanbul was in 1861-2. However, it proved to be a failed experiment because of the dominance of waqf property in the city. The real estate tax was reinstituted in 1874. Süleyman Sûdî, Osmanlı Vergi Düzeni (Defter-i Muktesid), ed. Mehmet Ali Ünal (Isparta, 1996): 63 and 76-7. For the cadastral survey of 1874, see Alp Yücel Kaya and Yücel Terzibaşoğlu, “Tahrir'den Kadastro'ya: 1874 İstanbul Emlak Tahriri ve
} 
ception of tax as a "sacrifice" that people make in order to secure and protect their wealth in the economic literature of the period. For example, according to Süleyman Sûdî (1834-96), an Ottoman intellectual who served in the financial bureaucracy, ${ }^{19}$ taxation was a value-creating mechanism as it was the basis of ownership rights. ${ }^{20}$

It is therefore no coincidence that one of the most important sources of income for municipalities came to be taxes on urban property. The idea of municipal services provided through the money of those who benefited from these services was one of the outcomes of the liberalization process in local governments. In fact, it was one of the factors behind the selection of Galata and Pera, the so-called European part of the city, for the establishment of the Municipality of the Sixth District in 1858 . The quality and quantity of real estate in the area was higher in comparison to other parts of the capital. The predominantly non-Muslim and foreign dwellers of the district were likewise supposed to have better knowledge of municipal administration due to their mental and geographic proximity to Europe-whatever this proximity entailed. The government believed that the idea of services in return for taxes could be actualized more easily in this part of the city since its property-owning inhabitants, in particular, were regarded to have comprehended this redistributive logic as a "true duty." In the cosmopolitan context of nineteenth-century Izmir, Zandi-Sayek takes this new understanding of urban duties as "one that bounded residents and authorities in a web of rights and responsibilities."22 The concept of honor was central to this ideology of services as both an expression of fight against corruption and as a rhetorical tool for strengthening local demand for autonomy. At the same time, the redistributive logic that was built into the principle of services in return for taxes on property, in particular,

Vergisi: 'Kadastro tabir olunur tahrir-i emlak,'” Tarih ve Toplum Yeni Yaklaşımlar 9 (2009): 9-58.

19 For biographical information and an evaluation of his work on Ottoman financial system, see Deniz T. Kılınçoğlu, Economics and Capitalism in the Ottoman Empire (London, New York: Routledge, 2015), 62-5.

20 "işbu mal üzerine vergi vaz' olunmasından dolayı kıymeti artacağı”: Sûdî, Osmanlı Vergi Düzeni (Defter-i Muktesid), 5 o.

21 "vazife-i sahîha": Ergin, Mecelle-i Umûr-ı Belediyye vol. 3, 1309-10; Christoph K. Neumann, "Marjinal Modernitenin Çatışma Mekanı Olarak Altıncı Daire-i Belediye," in 6. Daire, İlk Belediye 1857-1913: Beyoğlu'nda İdare, Toplum, Kentlilik Sergi Kataloğu, prepared by Beyoğlu Belediyesi and İstanbul Bilgi Üniversitesi Toplum, Ekonomi, Siyaset Araştırma Merkezi (TESAR) Yerel Yönetimler Araştırma Birimi, İstanbul (2004), exhibition catalog.

22 Sibel Zandi-Sayek, "Public Space and Urban Citizens: Ottoman Izmir in the Remaking, 1840-1890" (PhD Dissertation, University of California, 2001), 82. 
was inherent in the concept of şeref that was central to the relational values of urban property. Honor was what cemented the collective fiction of urban rent together as both a moral and economic theme.

As a case study, I have chosen to follow the traces of two different litigation processes both of which were initiated by female property owners. They illustrate how replanning after disasters touched upon important social issues such as corruption, justice, morality, equity, and the self-fashioning of communities. They also show the rhetorical world in which urban reforms were localized and translated into everyday language. The first case concerns the objection of Gülizar Hanım to the relocation of her property after the Mercan fire. Like many other property owners, she was unhappy with the inauspicious gap between the pre- and post-fire value of her plot. What appears to have informed people's reactions to such locational replacements was the new block (tarlâ) system that Ottoman reformers and planners tried to apply to the city. In comparison to the mere "enlargement" (tevsî) of narrow streets, the tarlâ system necessitated a larger scale of planning because it involved the creation of regular building blocks and an effective street network. ${ }^{23}$ In other words, the novelty of block as such was what confused and provoked people to object to the rearrangement of their parcels within a block in varying values. The "valuable" (şerefli) location of Gülizar Hanım's property simply became "valueless" (şerefsiz) when her plot was replaced after the fire and, according to her, this happened through ways that involved bribery. Bribery, on the other hand, invokes a language in which justice means the "completion of honor" (ikmâl$i$ nâmûs) that was violated by urban officials. The frequent employment of concepts like honor (nâmûs), justice ('adâlet), and equity (hakkânîyet) by her seems to be in tune with the use of the term "şeref," in that all the above meanings were interwoven within the politics of property location as both moral and economic notions.

Gülizar Hanım's example also amply demonstrates how far the administration of law was prone to corruption. Cases like hers resulting from urban reforms were not settled through qadi adjudication in this period. It was rather the administrative councils and commissions of various types which were mobilized for the resolution of property disputes. In the case of Gülizar Hanım, jurisdiction was fragmented between the Building Council (Ebniye Meclisi) and the Supreme Council of Judicial Ordinances (Meclis-i Vâlâ-yı Ahkâm-ı Adliye). The Building Council was an urban institution originally founded in 1831 under the name of the Directorate of Imperial Buildings (Ebniye- $i$ Hâssa Müdîriyeti) and was in charge of running building activities and urban 
development in the capital. In 1849, the name of the Directorate was changed into the Building Deputyship (Ebniye Mu'âvinliği) and tied to the Ministries of Commerce and Publics Works that merged and disunited so many times. ${ }^{24}$ Finally in 1852, it was renamed as the Building Council's Administration (Ebniye Meclisi İâresi). ${ }^{25}$ The Supreme Council founded in 1838 was, on the other hand, both a legislative body and a high court. It may also be seen as an umbrella organization under which a "system of administrative councils" was established throughout the Empire in the nineteenth century. ${ }^{26}$ Institutions like the Building Council had to answer to the Supreme Council.

But the caveat of Gülizar Hanım's case was that the Building Council was not only the judge but also the defendant: the officials of the Building Council were those whom Gülizar Hanım accused of corruption. This is why she continuously demanded the association of the Supreme Council in her case as a higher court of appeal. Therefore, the degree to which "the administration was judge in its own cause" 27 appears to be pivotal in understanding the notions of justice and corruption which historical actors fashioned during this period.

The second case involves a woman, Habibe Hanım, who had to defend her shop against a high-ranking bureaucrat who claimed the same property. Her case is an excellent example of property struggles among asymmetrical litigants in the sense that she had to make her case against Mahmud Nedim Paşa, one of the top bureaucrats of the century whom she alleged tried to seize her shop. Though she failed to maintain her previous level of livelihood, she was nonetheless partly successful. Her strategy was to mobilize the term "ma'delet," that meant both justice and equity as a power balancing discourse. Her opponent, on the other hand, could not be regarded as "corrupt" in a strictly legal fashion, at least, in this case. On the contrary, his game was a procedural one in the sense that he merely highlighted the compelling fact that the building of her shop was contrary to new building codes. He, of course, had to influence some people to make it officially visible. But the punchline of this case is that he had some shops next to hers that were likewise constructed against

\footnotetext{
24 Aziz Tekdemir, "Ticaret Nezareti (1839-1876)" (PhD Dissertation, Istanbul University, 2010).

25 Selman Can, "Osmanlı Mimarlık Teşkilatının XIX. Yüzyıldaki Değişim Süreci ve Eserleri ile Mimar Seyyid Abdülhalim Efendi” (PhD Dissertation, Istanbul University, 2002), 17.

26 Mehmet Safa Saraçoğlu, "Letters from Vidin: A Study of Ottoman Governmentality and Politics of Local Administration, 1874-1877" (PhD Dissertation, Ohio State University, 2007), 109; Avi Rubin, Ottoman Nizamiye Courts: Law and Modernity (New York: Palgrave Macmillan, 2011), 28.

27 Martina Künnecke, Tradition and Change in Administrative Law: An Anglo-German Comparison (Berlin, New York: Springer, 2007), 21.
} 
regulations. This is where "ma'delet" as a discursive term becomes tangible, reflecting the material basis of what justice and equity meant on the ground. Habibe Hanım's success lies in the fact that he also ended up losing his shops. Technically speaking, this case may not constitute corruption but it provides an evocative example through which discourses of corruption could be employed in ways that normative legality usually fails to capture. This case exposes the potential of urban tanzîmât as a collective and structural opportunity to act in a corrupt way, albeit procedurally. The example also shows the limits of the public/private dichotomy as an analytical category as the case turned into an institutional conflict, too.

Both cases are reconstructed from individual petitions that Gülizar and Habibe Hanım presented to different authorities, and official responses given to these petitions. Petitioning was an important part of the planning process which functioned as a legal tool to keep corruption in check. Petitions presented by property owners to different departments of the city administration played a role in fighting corruption by co-opting city dwellers into the state's surveillance technologies. They had a twofold utility from the perspective of the government. They provided a window of local knowledge on the ground that enabled the state not only to police and arrest corruption but also to fashion an image for itself as a just and regulatory power. They informed the government about the daily and ordinary appearances of corruption which could otherwise go easily unnoticed. The state needed to fashion itself as a legitimate power by creating channels for property owners by which they could object to the misdeeds of state officials during the reorganization activities. After all, seen in the mutual logics of public virtue, property owners had every right to complain when state actors violated the norms of disinterested and regular official behavior while their property was being expropriated for the public good.

Likewise, from the perspective of property owners, petitioning was a means of communicating their understanding of justice by positioning themselves against corruption. It was also a mechanism to involve themselves in local politics. The present study does not confine the question of local participation to liberal notions of electoral politics that developed in the nineteenth century as it takes the long-established practice of petitioning as a form of engagement in local affairs. It furthermore aims at questioning the masculine biases of urban politics by illustrating the role of women in city administration and property relations. Women like Gülizar and Habibe Hanım challenged the city's urban personnel who "represented" state institutions in varying capacities. Their challenge was constitutive of local networks through which governmental power was exercised and urban policies were formulated. Therefore, the somewhat insignificant presence of women should not obscure our vision of urban 
political power that was manifested in various forms in the day-to-day conflicts between state officials and female property owners.

Their examples demonstrate the fact that less visible dynamics of local administration might be more influential in shaping urban public values such as those of honor, justice, and corruption. However, the question of female agency here is relational rather than normative and "static" and gender is only one of the factors that shaped the way in which historical actors fashioned themselves in petitions. ${ }^{28}$ Other markers of life like social status, class, religion, and ethnicity had their impact on the form of positionality taken by individuals. Both Gülizar and Habibe Hanım were Muslim women of a relatively higher status. Moreover, Gülizar Hanım was represented by her son-in-law during the proceedings. Therefore, the picture drawn in this study is only a partial reconstruction of intriguing and complex social relations of property.

\section{Corruption}

Corruption is a nebulous concept. A continuous and flexible mediation between what is and what is not corrupt on the ground makes it difficult to define it. As Scott points out, scholars have traditionally laid too much stress on illegality by defining it as an "illegal private-regarding behavior in a public role." ${ }^{29}$ This is rather a modern notion of corruption that assumes a clear-cut separation between legal/illegal and public/private. Although attempts at reforming state apparatuses throughout the nineteenth century brought about changes that were centered on the professionalization and rationalization of bureaucracy, actual cases of corruption were much more complicated than the categories of that separation. It is legitimate to claim that pre-modern conceptions of corruption were less about individual official behavior than the general moral norms of the political system against which decline was measured. ${ }^{30}$

28 Leslie Pierce, "Seniority, Sexuality, and Social Order: The Vocabulary of Gender in Early Modern Ottoman Society," in Women in the Ottoman Empire: Middle East Women in the Early Modern Era, ed. Madeline C. Zilfi (Leiden, New York, Köln: Brill, 1997), 169.

29 James C. Scott, "The Analysis of Corruption in Developing Nations," Comparative Studies in Society and History 11, no. 3 (June 1969): 318. Scott uses the definition of corruption as given by J. S. Nye as representative. J. S. Nye, "Corruption and Political Development: A Cost-Benefit Analysis," The American Political Science Review 61, no. 2 (June 1967): 419.

30 Lisa Hill, "Adam Smith and the Theme of Corruption," The Review of Politics 68 (2006): $636-7$. 
But it is equally valid to argue that notions of morality were suggestively operative within the definitions of corruption against which justice was measured from the perspective of property owners as revealed in the nineteenthcentury cases under study in this article. Most probably, it did not take too much for property holders to confuse illegality with immorality as the line between the corrupt and non-corrupt was subject to the same netted relation. Indeed, it would be a mistake to confine the range of "uygunsuz" (improper) and "yolsuz" (irregular) behaviors, as the nineteenth-century language of morality and corruption most commonly had it, to those defined by laws. The labeling of such behavior reflects a much broader context than the one specified by the law. They usually reflect what was perceived as a violation of justice and of moral order rather than what was conceived as a legal transgression. ${ }^{31}$

The questions of whether justice was completely legal with respect to which property owners made a collective claim and how much of it stemmed from that collective fiction of urban rent are as relevant as the normative context of corruption. The production of corruption usually comes not only with moral and legal condemnation but also social legitimization. ${ }^{32}$ The slippery ground upon which we try to historicize corruption reflects a blurry continuum in the relations between the corruptor and the corruptee. One of the manifestations of this intricate relation can be deduced from a common binary complaint by property holders: undervaluation when a property was expropriated by the state and overvaluation when it came to taxation. Similar to the occasions that urban disasters like fires produced, the most comprehensive cadastral survey of the capital in 1874, for instance, must have created another larger communal opportunity to be corrupt. It is not difficult to imagine some official surveyors asking for bribes in return for smaller tax assessments. In the same way, it is also easy to picture some property owners bribing cadastral officials in order to make their properties look smaller on paper to decrease their tax burdens. Obviously, corruption requires some sort of negotiation and the forms and rules of negotiation are socially set. It is difficult to comprehend how far the

31 Lévy-Aksu's study on how the concept of honor was used by the Ottoman police forces in order to fashion an ideological and professional identity of their own during the Young Turk period also points in this direction. She demonstrates how the lines between illegality and immorality were blurry. Noémi Lévy-Aksu, "Building Professional and Political Communities: The Value of Honor in the Self-Representation of Ottoman Police during the Second Constitutional Period," European Journal of Turkish Studies 18 (2014): 5 . For a case study of how corruption is socially legitimized, see J. P. Olivier de Sardan, "A Moral Economy of Corruption in Africa?," The Journal of Modern African Studies 37, issue 1 (March 1999): 25-52. 
expression of the pot calling the kettle black proved to be true in this period of urban remaking in empirical terms. But such complaints were also shaped in a moral economy of property of which corruption was an integral part.

Likewise, the question of when corruption exactly becomes corruption hints at the diligent timing skills of historical actors and power relations rather than at the sanctions of the law. This is not to ignore, however, the legal developments of the century out of which corruption was "invented" as a punishable crime regardless, supposedly, of social distinctions. ${ }^{33}$ New laws did provide new social tools to mediate those skills. The criminal codes of the century, especially of $185^{8}$, were crucial in defining and specifying corruption as a legal category. They also specified penalties including imprisonment and dismissal from public office for different forms of official transgression like bribery, embezzlement, and abuse of office. ${ }^{34}$ From the perspective of the state, disciplined, regular, and disinterested official behavior was viewed as a precondition for the efficient functioning of state bureaucracy. Corruption, on the other hand, symbolizes moments of an ideological entanglement between rational and non-rational forms of bureaucracy. A supposed separation between the public and private was the bedrock of the ideological imposition of corruption as an "illegal" category, and salary was the measure by which to differentiate between private and public income. Salary, in other words, measured against pre-modern sources of income such as fees, taxes, and gifts, was a product of a rationale that separated the incomes of an institution from those of its officials. Rational bureaucracy might be a myth in empirical terms but its discursive ramifications were real as long as its "corrupt" officials were portrayed as individual deviations from its norms. Corruption became more individual and deviant in nature when state officials became salaried. ${ }^{35}$

Continuous attempts of the state to transform its officials into honorable civil servants in different branches of bureaucracy reveal a new consciousness as to the relation between practical and daily examples of good official behavior and state legitimacy. This was clearly visible in the measures that the government took in order to prevent corruption during the reorganization activities following the Hocapaşa fire. The government was aware of the fact that the planning of the burnt-down area of such a vast scale was prone to all sorts of corruption. One of the most critical aspects of the reorganization

33 Kırlı, "Yolsuzluğun İcadı: 1840 Ceza Kanunu, İktidar ve Bürokrasi."

34 Ibid., 114.

35 Steven Pierce, "Looking Like a State: Colonialism and the Discourse of Corruption in Northern Nigeria," Comparative Studies in Society and History 48, no. 4 (October 2006): 903 . 
process was the just measurement and reallocation of plots to their owners. It was a decisive and challenging moment for owners to define the boundaries of their property. It was subject to error, corruption, negotiation, persuasion, and confrontation whether between property owners themselves, or with the urban officials.

As a matter of fact, one of the reasons behind the establishment of a special commission in 1866 was to control corrupt relations that were likely to flourish in the environment created by the Hocapaşa fire and the planning activities that followed it. This special body of high-ranking Muslim bureaucrats appointed by the state was called the Commission for Street Improvement (Islâhât-ı Turuk Komisyonu). The duty of these officials was to reorganize the narrow and crooked street pattern and allocate plots in destroyed neighborhoods to their owners according to proper rules and regulations. ${ }^{36}$

The just reallocation of parcels was not just an empty concern as complaints of property owners already started to pile up prior to the institution of the Commission for Street Improvement (cSI). The Fire Office at the Building Council's Administration was the department responsible for the reorganization of the area until the CSI was instituted in 1866. But the scale of reorganization after the fire was extraordinary and complicated and it became clear that the Fire Office was a corrupted institution. ${ }^{37}$ When a fifteen-article bill announced the creation of the CSI in the official newspaper Takvîm-i Vekâyic, the "guarantee of property owners' rights" was the point that was made clear as the "fundamental duty" of its operations. ${ }^{38}$ This was not an ordinary founding principle that was pronounced out of discursive formalities. It was followed by institutional changes and several measures to ensure order and justice in the conduct of government officials.

The CSI first had to put officials whom it considered corrupt under close scrutiny. To this end, all the officials working at the Fire Office and the Building Administration for the reorganization of the area were taken into the retinue of the CSI. According to the CSI, these officials caused "endless disputes" because of "all sorts of impropriety" in which they engaged. ${ }^{39}$ Although some police officers under the command of the CSI were ordered to investigate and resolve

\footnotetext{
36 вОА, I.MVL, 550/24667; воА, і.DH, 572/39882; вОА, I.MVL, 555/24895; воА, і.MVL, $571 / 25660$.

37 BOA, I.MVL, 571/2566o.

38 "Ashâb-ı emlâkın zamân-ı hukûku"; "esâs-ı vazîfe": Takvîm-i Vekâyi', 1 July 1866, article 5.

39 "münâza'atın arkası alınamayub dürlü dürlü uygunsuzluklar zuhûra gelerek”: воА, i. MVL, $571 / 25660$.
} 
these conflicts, the officials' "sins were at a point beyond correction." ${ }^{\text {" } 0 ~}$ The cSI kept "hearing" about their "doing some irregular and improper things" as a consequence of their "incapacity." ${ }^{1}$ Therefore, Mehmed Efendi, the head functionary, together with some other officials under his command were "expelled" from the CSI and redistributed elsewhere because of their misconduct. ${ }^{42}$ In place of Mehmed Efendi, Hafiz Ahmed Bey, a colonel in the artillery corps, was appointed and all the building officials and engineers were to answer to him.

Another measure to prevent corruption among the officials working for the CSI was to pay their salaries regularly without delay or deficiency. In the reports that the CSI presented to the government regarding their operations, expenses, and future plans, the payment of the officials and engineers' salaries appears to be central to the problem of corruption. The CSI acknowledged the situation straightforwardly for officials were likely to engage in some "intrigues" (fesât) in their business because of the "necessity" (zarûret) arising out of these delays and deficiencies. ${ }^{43}$ In order to prevent this, the CSI had to pay their wages from its own budget. ${ }^{44} \mathrm{~A}$ raise in their salaries was also another objective which the CSI tried to realize.

A further measure designed by the CSI to avoid possible abuses by officials on the ground who measured and allocated plots to owners was to publish notifications in the newspapers for the owners to be present during the measurement of their land. ${ }^{45}$ Property holders were required to "show the borders of their land" and then to receive a certificate given by the officials regarding the size of their property ${ }^{46}$ If they still had a doubt, they were free to hire an expert whom "they trusted" to measure their land for a second opinion. ${ }^{47}$ If there was still a "mistake," they had two weeks starting the day after they obtained their certificates to object by applying to the Building Administration. For those who "did not have anybody to measure" their plot, the csi made some officials from offices outside the surveying department of the Building Administration

\footnotetext{
40 "hatîi'iyyât-ı vâkı âsı kâbil-i ıslâh olamayacak dereceye gelmiş olmasıyla": BOA, İ.MVL, $571 / 25660$.

41 "bazı yolsuz ve uygunsuz şeyler yaptıkları işitilüb”; "ehlîyetsizlik": BOA, İ.MVL, 571/2566o.

42 "def' olunarak"; "âhar işte kullanılmak üzere”: BOA, i.MVL, 571/2566o.

43 BOA, İ.DH, $572 / 39882$.

44 BOA, i..DH, $572 / 39882$.

45 Takvîm-i Vekâyi 26 February 1866, 27 March 1866 and 24 April 1866; Tasvîr-i Efkâr, 20 September 1865, 28 September 1865 and 14 October 1865.

46 "arsaları başlarında bulunarak hudûdlarını göstermeleri”: Takvîm-i Vekâyi', 26 February 1866.

47 "emniyet ettikleri": Takvîm-i Vekâyi', 26 February 1866.
} 
available to do the job. ${ }^{48}$ For those who were not in Istanbul at the moment of the measuring and allotment, the imâm and muhtâr (headman) of the neighborhood were designated responsible for the follow-up. ${ }^{49}$

All these measures taken by the csi to discipline its officials show the degree of the importance given to the eradication of corruption during the reorganization of the burnt-down districts. The complaints of property owners, nevertheless, continued to pile up after the creation of the CSI in 1866. Furthermore, no matter how hard the csi tried to control corruption, the problem was much more structural than its members possibly imagined. The following cases demonstrate how far the rationalization and professionalization of urban bureaucracy was successful before and after the establishment of the CSI. They also illustrate the extent to which the ideals of morality and legality were built into politics and administration.

\section{The Problem of Gülizar Hanım with the Building Council}

Urban tanzîmât left many property owners dissatisfied with the redevelopment schemes that followed large fires which consumed parts of Istanbul in the second half of the nineteenth century. Among them was Gülizar Hanım, a widow over 80 years old and in poor health who fashioned herself as in tears with her "honor broken" (şikest-i nâmûs) because of the injustice that ensued the conflagration. ${ }^{50}$ Her son-in-law, Mehmed Fevzi Efendi, acted as her representative during the proceedings; he was no stranger to the intricate ways of Ottoman bureaucracy as he himself was an official serving at the Ministry of Foreign Affairs. Her deceased husband was a man of considerable stature as well. He was the former director of the Imperial Fez Factory but it is not clear whether Gülizar Hanım acquired her properties, a shop and adjoining house, through her husband. ${ }^{51}$ Her properties had a very "şerefli" (valuable) location on the Yüzükçüler Street in Mercan as they had an "esteemed corner"52 position on a crossroad of important streets and "a perfect open view all around" that featured the Golden Horne. ${ }^{53}$ After the fire, however, a new street was created that sliced through the middle of her property, paving over a water

\footnotetext{
48 "mesâha ettirecek kimesnesi olmayanlar": Takvîm-i Vekâyic, 26 February 1866.

49 Takvîm-i Vekâyic, 26 February 1866.

50 "dâcîye-i dîrînelerinizi ağlatmayub": BOA, Meclis-i Vâlâ (hereafter MVL), 466/19.

51 BОА, MVL, 466/19; ВОА, MVL, 473/57; ВОА, MVL, 472/5.

52 "köşe-i mu'teberâde": BOA, MVL, 466/19.

53 “cevânib-i erba'adan açıklıkla nezâret-i kâmileyi câmi'”: BOA, MVL, 473/57.
} 
reservoir, three wells, and a big cellar that she possessed there. Furthermore, Gülizar Hanım faced the bitter prospect of losing the corner site because her land became the object of a contentious relocation plan.

Although it is quite difficult for us to fully comprehend the content of this dispute in the absence of a map, it seems that the new street produced a new corner and the official responsible for the reorganization of the area, a certain Hüsnü Efendi, decided to give this new corner site to someone named Hacı İbiş Ağa, a maker of amber mouthpieces for pipes, because his cellar fell within the boundaries of this re-plotted piece of land on the corner. Gülizar Hanim alleged that losing the highly coveted corner location and the view resulted in the decrease of her properties' value. ${ }^{54}$ Upon the objection of Gülizar Hanım, two building assistants, Hüseyin and Esad Efendis, were assigned to solve the problem. They decided in favor of Hacı İbiş Ağa based upon the rule specified in the building regulation that planning officials must try to adhere to what was deemed the original constitution of the property in question, which included factoring in the location of cellars. ${ }^{55}$ However, it appears that other variables such as location and auspicious views did not figure into the picture drawn by the urban officials. At the beginning of the dispute, Hüsnü, Hüseyin, and Esad Efendis suggested a quick solution to the problem: Gülizar Hanım could have the corner site if she accepted to pay the value of Hacı İbiş Ağa's cellar to him. She agreed and, consequently, in the presence of some neighbors, they reached the final decision.

Yet later, these officials acted hesitantly in implementing their decision as Gülizar Hanım claims. Therefore, she presented a petition to the ministries of Commerce and Public Works and her son-in-law went to the Building Administration to explain the situation to the director. According to the allegations of Mehmed Fevzi Efendi, they had "deceived" (iğfâl) the director of the Building Administration by hiding their initial decision and somehow manipulating the original map of the place. As a result, the director did not pay attention to the claims of her son-in-law. Moreover, when Mehmed Fevzi Efendi told the director that he would present a petition to the Supreme Council in order to seek justice, the director "got angry and spurned him away, saying many insulting things that are against the honor of humanity and ill-suited to

54 “150.00o guruşluk hukûk-ı 'acizânemin ibtâli”: BOA, MVL, 466/19.

55 Turuk ve Ebniye Nizâmnâmesi, 1280 [The Street and Building Regulation of 1863], article 12, in Gül Güleryüz Selman, “Urban Development Laws and Their Impact on the Ottoman Cities in the Second Half of the Nineteenth Century" (MA Thesis, Middle East Technical University, 1982), A51. 
his office."56 Enraged, the director even attempted to "apprehend" (habs) him. In contrast, Mehmed Fevzi Efendi appears quite even-tempered in the petition and maintains his idea that "claiming one's right is no offense." 57 He added that the director had no right to "insult him and break his honor" for wanting to seek justice. ${ }^{58}$

The response of the Building Council unsurprisingly denied all these claims. As they argued, they were "gentle" (mülâyimâne) towards Mehmed Fevzi Efendi when explaining that Gülizar Hanım was given new land "in a just way as in similar cases." ${ }^{59}$ However, he would not listen and went so far as to accuse the officials of the Building Administration of having accepted a "bribe" (rüşvet). They took his "insulting language" extremely seriously and responded by arresting him and sending him to the office of the gendarme. ${ }^{60}$ Further responding to his "imputation of bribery," they also indicated that they were prepared for an official hearing in the Building Council in order to prove their just conduct. ${ }^{61}$

Around a month later, Gülizar Hanım had to present another petition. This time there was a different problem. Hacı İbiş Ağa started to construct a building on the land that she claimed to be hers. This was contrary to regulation because the land was still being disputed. Before a final verdict was reached, no one was allowed to use the land. But apparently, this was no obstacle for Hacı İbiş Ağa as he had already started building. According to Gülizar Hanım, it was a deliberate strategy that he could stake out a claim to the land by using the building and the money that he would spend for it as a legal bargaining chip. ${ }^{62}$ His timing was, as she keenly stressed, perfect: he chose to begin construction during the Muslim feast of sacrifice when the government offices were closed. Therefore, Gülizar Hanım felt the need to present a petition in order to expose his deceptive plan and demanded that Hacı İbiş Ağa should be checked. She also requested an official inquiry to determine whether or not the Council's officials knew about the ağa's scheme. ${ }^{63}$ In about two weeks, she and her

56 "pür-hiddet olub çâkerlerini tard ve bir takım hakâretle nâmûs-ı insâniyete düşmeyen ve makâm-ı me'mûriyete yaraşmayan bir haylî kelâm-ı nâ-becâ": BOA, MVL, 466/19. "hakkını taleb ve istid'â eylemek insana bir kusûr olmadığı": BOA, MVL, 466/19.

$5^{8}$ "hakâret ve şikest-i nâmûs eylemek": BOA, MVL, 466/19.

59 "usûl-i hakkâniyete ve emsâline tatbîkan": BOA, MVL, 466/19.

6o "itâle-i lisân": BOA, MVL, 466/19.

61 "rüşvet 'azvi": BOA, MVL, 466/19.

62 "merkûm ise şu yolda edeceği masârıftan dolayı bir ser-rişte ittihâz ederek güyâ umûruna takviyet vermek ve muhahharan bir takım dacvâ ihdâs eylemek emelinde bulunduğu": BOA, MVL, $572 / 5$.

63 BOA, MVL, 472/5. 
son-in-law submitted yet another petition on the matter. However, it seems that their petitions were not taken into consideration. On the contrary, the Building Administration "completely permitted the construction of the building" as Gülizar Hanım claims in another petition. ${ }^{64}$ Their answer was the same: it was Hacı İbiş Ağa's right to claim and construct on that land and Gülizar Hanım's claims were "futile" (vâhî). ${ }^{65}$ In the meantime, a testimonial (şehâdetnâme) signed by six persons, most probably some of her neighbors, followed all these petitions in order to back up Gülizar Hanım's claims. They stated their conviction for the official record that the locational şeref of the new plot given to her was indeed not equal to that of her former land and, as it was, this relocation was an "exceeding injustice and great loss" for her. ${ }^{66}$

Gülizar Hanım's reply to the response of the Building Administration arrived shortly. For her, the urban officials were "telling a story"67 full of "gossip" (kîylükâl) and "resentment" (garaz) and "wrong accusations" (isnâdât) "in order to hide and drive away" 68 the loss that they caused her. She firmly states that if they were ready for a hearing, she was ready too, though the solution did not lie in a hearing, as she was sharp enough to add. The evidence was clear enough: it lay in the re-allotment map that Hüsnü, Hüseyin, and Esad Efendis were hiding as well as in the testimony of the neighbors. As she understood the situation, there was no need for a hearing in the ostensibly corrupt "Council." 99

One of Gülizar Hanım's petitions provides a glimpse into what the collective fiction of urban rent was about. As the central government promoted it after the Hocapaşa fire, every "ash-orphan" (kül öksüzü $)^{70} \mathrm{dweller}$ of the city should feel "hissemend" (having a share or interest) in urban "prosperity" (ma'mûriyet). ${ }^{71}$ She thought accordingly that "all these [expropriated properties] were sacrificed by the people on the ground with the expectation that [their properties] would attain more value in the future" as a result of urban redevelopment. ${ }^{72}$ The interest that people were expecting to gain from the reorganization of

\footnotetext{
64 "bütün bütün ebniye inşâsına ruhsat verilmiş": BOA, MVL, 473/57.

65 BOA, MVL, 472/5.

66 "fevkalâde gadr ve hasâr-i küllî”: BOA, MVL, 472/5; BOA, MVL, 473/57.

67 "hikâye beyân etmekte olduklarr": BOA, MVL, 473/57.

68 "setr ve def' etmek içün": BOA, MVL, 473/57.

69 "'abd-i âcizleriyle heyetçe muhâkeme olunacağı dahi ifâde kılınmış ise de bunun heyete dokunur bir yeri olmayub": BOA, MVL, 473/57.

70 Ergin, Mecelle-i Umûr-ı Belediyye vol. 3, 1122.

71 Ibid., 1288

72 "ilerüde daha ziyâde nâil-i şeref olunur mütâla'asıyla bunların cümlesi beyne'l-ahâlî fedâ olunmuş": BOA, MVL, 473/57.
} 
their environment was "public" as it was collective and individual. ${ }^{73}$ However, her situation was quite the contrary. The officials responsible for the replotting of her land turned this "public interest" into a "private" one by giving her land to Hacı İbiş Ağa, by implication, through ways that involved bribery. ${ }^{74}$ After several weeks, she demanded again that the Supreme Council should obtain the map that Hüsnü, Hüseyin, and Esad Efendis supposedly concealed. ${ }^{75}$

At first view, her situation looks like an ordinary case of corruption that caused great pain for Gülizar Hanım and her case does seem plausible. Unfortunately, however, we do not know how the case ended. Therefore, it is difficult to ascertain which party was telling the "truth" even if we accept that there were only a single one-sided truth to tell. Even if we assume that Hacı İbiş Ağa was indeed in the possession of the cellar that fell within the borders of the plot on the corner after the redevelopment and Gülizar Hanım had actually owned the corner position with an open sea view before the fire, a simple question still remains: Why did the urban officials choose the cellar over the corner location given the fact that the building regulation of 1863 includes articles of rather limited specification and does not enumerate hierarchically the qualities of a property like position vis-à-vis streets and corners, open air and light, views, or having a cellar? ${ }^{76}$ Yet, what appears to be more important is that the question of locational value was as social as technical in that the testimony of Gülizar Hanım's neighbors was important as much as the map of the area was central to the matter, upon both of which Gülizar Hanım placed equal importance in her petitions. Even though the scope of such locational replacements appears to be limited, usually on the same block, the changing "dynamics of property location" in a changing rent market informed people's reactions to urban replacements in this period. ${ }^{77}$ In any case, the scope seems less important than the emergence of the block system as the dominant form of urban replanning.

Regardless of all these questions concerning locational values and of all the "lies" and "truths" in Gülizar Hanım's story, another pivotal aspect of her case is that the Building Council functioned not only as the judge but also as the defendant. The officials who were supposed to solve her problem were the very

\footnotetext{
73 "tesviyeden murâd 'umûmun menfa'ati olub": BOA, MVL, 473/57.

74 "bu menâficimizi menfacat-ı husûsîye-i şahsîyeye inhisâr ile”: BOA, MVL, 473/57.

75 BOA, MVL, 473/57.

76 Turuk ve Ebniye Nizâmnâmesi, 1280 [The Street and Building Regulation of 1863], in Selman, "Urban Development Laws and Their Impact," A47-A64.

77 Russell Schiller, The Dynamics of Property Location: Value and the factors which drive the location of shops, offices and other land uses (London, New York: Spon Press, 2001).
} 
officials who created the problem itself. Even though urban institutions like the Building Council were, in principle, under the supervision of the Supreme Court, we see that the Building Council had the capacity to hear her case and issue a legal decision. In addition to this, the same Council also attempted to detain Gülizar Hanım's representative even before such an authority was legally specified in the Regulation of 1868 for the Municipal Administration of Istanbul. ${ }^{78}$ The double role of the Building Council posed a conflict of interest in the dispute which characterized her continuous efforts to bring her case before the Supreme Council. This also explains why she needed to draw attention to the procedures to be followed in settling land disputes such as hers, procedures regarding the investigation of maps, consulting to the office of the cadastral registry, and the hearing of witnesses, all of which urban officials were no doubt aware.

In such a situation, who could expect the Building Council to be impartial? Definitely not Gülizar Hanım. After all, the building director did not believe her representative when he went to him in order to explain the misconduct of Hüsnü, Hüseyin, and Esad Efendis. This is why she continuously demanded the engagement of the Supreme Council in her case as a higher court of appeal. There is, of course, a reason for which Mehmed Fevzi Efendi narrated in detail how the building director "got angry" when he told the director that he had no choice but to apply to the Supreme Council. That "claiming one's right is no offense" was the backbone of his rhetoric against the director. In the face of the director's insults that were "against the honor of humanity," it was natural for them to appeal to the Supreme Council. Gülizar Hanım and her son-inlaw were also quite tactful when they pointed to the procedures to be followed in settling such property disputes. They rejected any hearing in the Building Council without any investigation done regarding the map of the area and the testimony of the neighbors. That Gülizar Hanım was given new land "in a just way as in similar cases" was just a usual answer that they could not accept. Nevertheless, justice was whatever she and her representative made of it during the proceedings, which they centered around the concept of honor. It was not only a matter of legality but also one of morality for Gülizar Hanım as she defined corruption and injustice as a violation of her honor. At the interface between legality and morality was the concept of honor that functioned as a rhetorical tool against corruption.

78 Dersacâdet İdâre-i Belediye Nizâmnâmesi [The Regulation of 1868 on the Municipal Administration of Istanbul], article 9, in Ergin, Mecelle-i Umûr-ı Belediyye vol. 4, 1618. 


\section{The "age of justice and equity" and Habibe Hanım vs Mahmud Nedim Paşa}

Habibe Hanım, a resident of the Ayasofya neighborhood and owner of a grocery (bakkâl) next to the ferry quay near the lemon and dried fruits wharf on the shore of the Golden Horn, was a woman who likewise had to defend herself against an obscure situation that emerged in the process of reorganization following the Hocapaşa fire in 1865 . In her case, urban tanzîmât applied selectively because her shop was designated to be demolished amongst others close by along the seashore. She had a particular person in mind to accuse for the situation, the owner of a next-door shop. She refrained, however, from revealing the identity of her neighbor until her third and last petition. It turns out that he was, unlucky for her, a very powerful man. She believed that he wanted to annex her shop. She was all alone against him, "having no male" representative who could help her. ${ }^{79}$ Nevertheless, it was the "age of justice and equity," she wrote, that would help her neutralize this selective "injustice" ( $g a d r) .80$

Her menacing neighbor was Mahmud Nedim Paşa, none other than the future grand vizier of the Empire and last successor of one of the great tanzîmât architects, Ali Paşa. Following the footsteps of his father's bureaucratic career, Gürcü Mehmed Necip Paşa, governor of Bagdad (1842-9), Mahmud Nedim Paşa started his official life in 1831 . Before he was appointed grand vizier for the first time in 1871 , he held various high-ranking positions including governorships and ministry directorships. His grand vizierate represented the rise of a political faction that was repressed in the 186 os by the influence of Ali Paşa and Fuad Paşa ${ }^{81}$ Known for his "anti-tanzîmât" treatise in which he advocated the ideal of an absolutist sultan, he developed close relations with the Palace. ${ }^{82}$ Over the course of his bureaucratic trajectory, he also made enough enemies to tarnish his reputation. He was known for his "immorality" (sû́-i ahlâk) and he was associated by many with "corruption" (irtikâb). ${ }^{83}$ Faced with such accusations, he tried to defend himself in his writings. Unlike his peers, he states, he "did not have any landed property except for a house that he inherited from his

79 “zükûrdan kimesnem olmayub": воА, Sadaret Evrakı: Mektubu Kalemi: Mühimme Kalemi Evrakı (hereafter A.\}мкт.мнM), 431/64.

8 o "asr-1 ma'delet": воА, А.\}мкт.мнм, 431/64.

81 Butrus Abu-Manneh, "The Sultan and the Bureaucracy: The Anti-Tanzimat Concepts of Grand Vizier Mahmud Nedim Paşa," International Journal of Middle East Studies 22, no. 3 (August 1990): 257 .

82 Ibid.; İbnülemin Mahmut Kemal İnal, Osmanlı Devrinde Son Sadrazamlar, vol. 1, (İstanbul: Dergah Yayınları, 1982), 256-314.

83 Mithad Paşa, Mirat-ı Hayret, quoted in İbnülemin Mahmut Kemal İnal, Osmanlı Devrinde Son Sadrazamlar, 263. 
father along with an ordinary mansion on the seashore." 84 In fact, he "did not have anything but honor and integrity as capital in this world" as he states in a document he wrote to the grand vizierate asking for a new appointment in $1855 .^{85}$

But apparently, as his case with Habibe Hanım demonstrates, the kind of "honor and integrity" that the paşa claimed to have did not prevent him from using his stature and connections as a high-ranking bureaucrat for personal interests. Habibe Hanım was obviously in a disadvantageous position against him. However, even though she underlined in her second petition that she did not have any "male" representative, most likely so that she could attract some sympathy by fashioning herself as a lonely helpless woman, she was somehow supported by Server Bey, then the prefect of the city and a member of the CSI. Server Bey supported her because doing so was in the interest of the cSI. In that sense, maybe she was lucky that their case turned into an institutional conflict involving the Şehremâneti, the Building Administration, the CSI, the Ministry of Imperial Religious Endowments, the Harbor of Istanbul, the Ministry of the Navy, and the Imperial Shipyard. Therefore, their case not only presents some of the dynamics of corruption but also reveals inter-institutional tensions. Although corruption was a new "invention" defined in criminal codes, the case of Habibe Hanım against Mahmud Nedim Paşa did not need to refer to any invention as such. ${ }^{86}$ Already made into a strategic tool to mediate social relations, corruption involved in their case was not defined in terms of normative legality as a simple conflict between a "public" and a "private" person but in a wider conception of justice and equity (ma'delet) in an inter-institutional context.

The story goes back to the 1840 s when a fire destroyed her shop that was her "means of livelihood." ${ }^{77}$ She states in her first petition that after this fire, the property continued to be used as a wooden booth (salâş) until the new urban codes made her makeshift solution illegal. ${ }^{88}$ Consequently, after her shop was pulled down, Habibe Hanım presented her first petition asking for permission from the Imperial Shipyard (Tersâne-i Âmire) in 1867 for her store to be reconstructed with proper materials. But the Imperial Shipyard was a rather curious place to apply for such matters. In the response to her petition, she was told to appeal to the Building Administration given that the Imperial

84 "pedermande bir hane ve bir adi sahilhaneden başka bir emlâk ve akara mutasarrıf olmadıktan": quoted in ibid., 311-2.

85 "bu âlemde namus ve istikametden başka sermayem olmadığından": quoted in ibid., 262.

86 Kırl, "Yolsuzluğun İcadı: 1840 Ceza Kanunu, İktidar ve Bürokrasi."

87 "medâr-ı ta'yîş": воA, А.\}м Кт.мнм, 431/64.

88 "salâşlar yıkılub kârgîr olunacağı nizâmı vecihle": вОА, А.\}мКт.мн М, 431/64. 
Shipyard was not the right institution to which she should apply. Soon enough, another intriguing thing happened after her case was transferred to the latter institution. Having investigated the matter, the Building Administration wrote back stating that "there is no such a plot of shop in that location." 89 Therefore, the need arose to simply check if such a plot even existed..$^{90}$ The officials from the Administration then approached the Ministry of Imperial Religious Endowments since they determined that the shop was a waqf property. As it turns out, the shop did exist and it belonged to the waqf of the Great Ayasofya Mosque; it was verified that the title deed held by Habibe Hanım was indeed authentic. In the end, they granted her permission to rebuild her shop.

Of course, this was not a simple issue that could be explained easily as there was merit in her decision to apply to the Imperial Shipyard in the first place. Her foresight becomes visible when the same institution stopped the reconstruction. In response, Habibe Hanım submitted her second petition to the Imperial Shipyard. She summarized what happened up to that point and once more asked for the permission to resume rebuilding her shop. But this time, it was not going to be easy for her to solve the problem. The dispatches written by different offices of the Imperial Shipyard recalled the claim of the Building Administration and even challenged the very existence of her shop's plot. The Shipyard, in fact, pointed out that this was not a matter of a land dispute because her shop was not even on the shore but, rather, hastily built over the water on a pier. Apparently, the shop was anchored in the sea with the help of piles. But if she had not had any land on the seashore, why and how did the Building Administration give her permission to build such a structure? Moreover, how did she come to have a title deed that proved that she did have some form of property? The same dispatches also reveal that her land was expropriated during the reorganization of the streets in the area after the fire that happened in the 1840 s and, as compensation, yet "contrary to the rules,"91 she was "anyhow" given "a place over the sea" by the Ministry of Imperial Religious Endowments instead of a place somewhere on land. ${ }^{92}$ Since the construction over the water involves the issue of sea traffic given her shop's proximity to the wharf and the ferry quay and hence "strictly forbidden," the Imperial Shipyard had no choice but to stop it. ${ }^{93}$

\footnotetext{
89 "mahal-i mezkûrda öyle dükkân ‘arsası bulunamadığı”: воA, А.\}мКт.мH M, 431/64.

90 "zikr olunan 'arsanın el-hâlet-i hazihi mevcûd ve mezbûre 'uhdesinde olub olmadığının": воА, А.\}М Кт.Мнм, 431/64.

91 "mugâyir-i nizâm olarak": воА, А.\}мКт.мнм, 431/64.

92 "her nasılsa”; “denizden yer": воА, А.\}мкт.мнм, 431/64.

93 "kaviyyen taht-ı memnû́iyette bulunduğu”: воA, А.\}м Кт.мнм, 431/64.
} 
But then, why did the Imperial Shipyard raise all these issues only after Habibe Hanım presented her second petition while declining her first petition by referring the case to the Building Administration? The initial response from the Harbor of Istanbul to her second petition first had to justify why they did not prohibit the reconstruction in the first place. The strategy that they appear to have employed hinges on an excuse. They simply pretended that they did not know that the shop was a pier over the water even though Habibe Hanım openly mentions the piles in the sea in her first petition. As they present it, the real problem was something else: it was the problem of whether she possessed a piece of land or not. This was not an ordinary issue to bring to the fore in that it mainly passed on the problem to another institution that gave her permission despite the fact that her land was gone in the 1840 . The real solution that they suggest is that Habibe Hanım should be given a new place somewhere else according to the regulations, which meant that those regulations should be under the purview of the CSI.

What was the reason behind this change in the tone and the direction of the proceedings? The career pattern of Mahmud Nedim Paşa was probably the most important factor. When Habibe Hanım applied for the first time to the Imperial Shipyard in 1867 , the paşa was the Minister of Judicial Pleas (De $\hat{a} v \hat{\imath}$ Nezâreti). He already became the Minister of the Navy in March 1868 when she appealed to the same institution for the second time, which most probably made the situation more difficult for her. Nevertheless, as mentioned, she was helped by Server Bey. It would be naïve to believe that he helped her out of his generosity or deep commitments to mercy and justice. We do not know whether there were pending personal conflicts between Server Efendi and Mahmud Nedim. But we know that Server Efendi did not want the csi to compensate her. His aim seems to avoid any reimbursement that would burden the CSI. Therefore, he sided with Habibe Hanım against Mahmud Nedim. He was as successful as the paşa in staging a very procedural counteraction. Although he was in touch with Mahmud Nedim via several dispatches that they wrote to each other, he was studiously invisible when it came to supporting Habibe Hanım.

Even though Habibe Hanım found Mahmud Nedim Paşa responsible for the demolition of her shop, we still do not know exactly which institution had her grocery stall pulled down. It is possible that the CSI, whose duty was to reorganize the area under the Şehremâneti, initiated the process with reference to the imposition of masonry construction. The paşa, on the other hand, would have seen it as an opportunity to seize Habibe Hanım's shop by making the reconstruction completely "forbidden" whether or not it consisted of masonry. This would require some help from the Navy to prove that the construction 
in question was against harbor regulations and, hence, it would explain why Habibe Hanım presented her first petition to the Imperial Shipyard. What is certain, regardless of how the dispute originated, is that Mahmud Nedim Paşa did want to annex her shop with the help of some people from the Imperial Shipyard. However, the nature of this help is not clear, either. The answer given to Habibe Hanım's earliest petition does not absolutely confirm a full-fledged institutional collaboration since it did not reject her demand once and for all. Instead, she was told to apply to the Building Administration. We can assume that Mahmud Nedim Paşa's relations with the Imperial Shipyard were only on an ad hoc basis at the time rather than institutionally coordinated, given the fact that he was not yet named as Minister of the Navy. But when Habibe Hanım presented her second petition, he was already entrenched in his new powerful position in the Navy.

In addition to the answer of the Harbor of Istanbul, Mahmud Nedim Paşa personally wrote a note addressed to the Şehremâneti. He repeated the same problem and likewise suggested the same solution. Server Efendi, however, challenged the paşa's maneuvering. Since it was the Harbor Administration that deemed the building of her shop harmful, it was their responsibility to compensate Habibe Hanım. Otherwise, it was completely legal according to the Building Administration. Mahmud Nedim Paşa wrote another note to Server Efendi. Unsurprisingly, he did not accept such a responsibility. Once more, he referred to the original problem: the Building Administration gave her a place over the water which was apparently contrary to the rules. Server Bey was obliged to accept and, thereupon, he found another institution to stage his battle. Was it not the Ministry of Imperial Religious Endowments which confirmed that Habibe Hanım had a plot on which her shop was located? The Building Administration gave her permission only after the confirmation of the Ministry. Therefore, he came to the conclusion that it was the Ministry's fault, hence their responsibility. The reaction of the Ministry was straightforward: it was not their job to allocate plots in areas reorganized after fires. When Habibe Hanım's shop burnt down in the 1840 s, it was not them who failed to give her a new plot. In this case, they "naturally" (bit-tabi $i)$ gave her the old place that was actually expropriated and added to the street. ${ }^{94}$ It appears that Server Bey's last attempt to pin the responsibility on another institution did not result in a decision in his favor.

In the end, he left the matter open-ended by stating that the budget of the CSI was not enough to compensate Habibe Hanım and therefore, the issue should be referred to another institution. From the last dispatch he wrote, we 


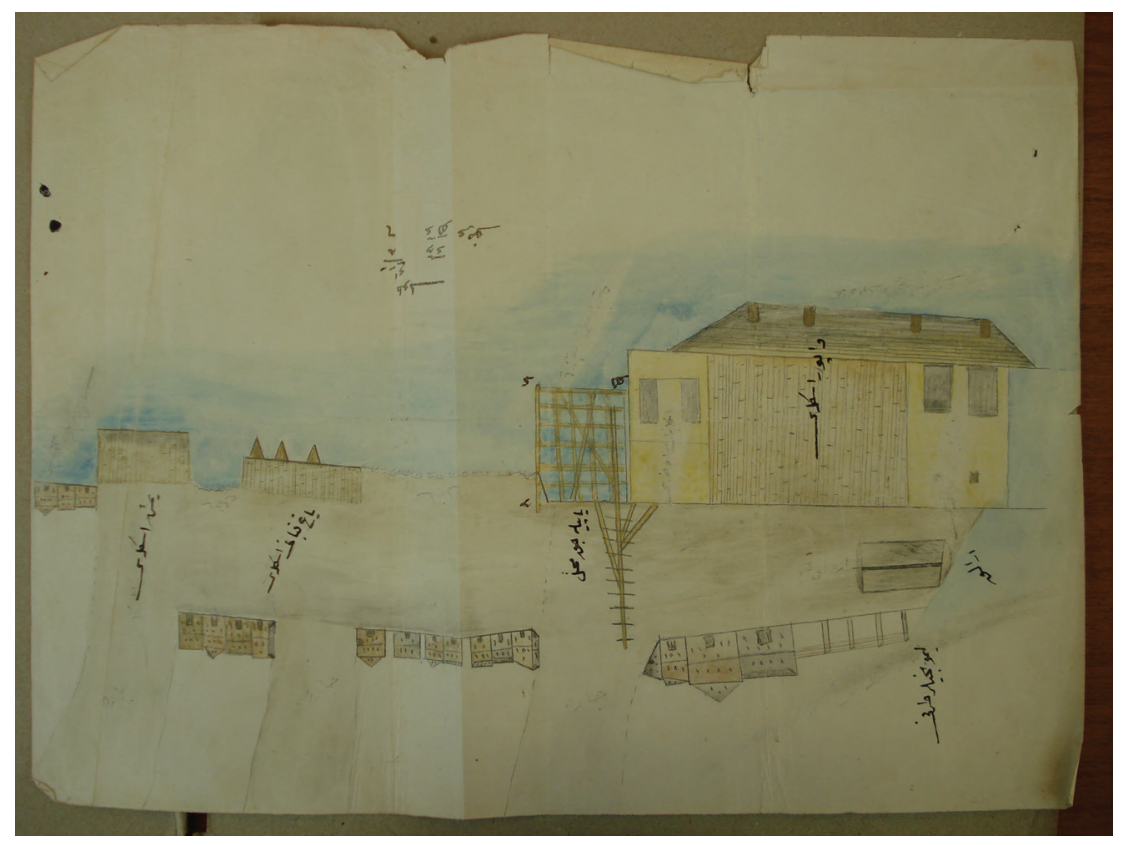

SOURCE: BOA. A.\}MKT.MHM 431/64. ON THE SEASHORE, FROM RIGHT TO LEFT: THE FERRY QUAY (VAPUR ISKELESI); HABIBE HANIM'S SHOP (YAPILACAK MAHAL); THE OIL QUAY (YAĞKAPANI ISKELESI); AND THE WHARF OF DRIED FRUITS (YEMIŞ ISKELESI).

also learn that he ordered the csi to investigate the so-called harm that Habibe Hanım's grocery posed to the wharf and ferry quay. Upon his order, some members of the CSI with several engineers in their retinue investigated the matter and they concluded that the problem could be resolved if the grocery were to be moved back a little from the sea to make it in line with the adjacent shops. Again, this was not a random decision but rather a calculated strategy since he of course knew that some of the adjacent shops belonged to Mahmud Nedim Paşa. He deliberately attempted to put his shops in the firing line, too. However, it did not yield the intended effect. The Imperial Shipyard did not accept the suggestion of the CSI. In the end, the experts of the CSI estimated the value of her shop and it was decided that Habibe Hanım was to be given $65^{\circ}$ piasters per zirấ, 95 in total, 27,000 piasters for 42,5 zirâ's.

Unhappy with this result, Habibe Hanım presented her final petition in a last ditch effort to gain the compensation and justice to which she felt entitled. She claims in the very beginning that Mahmud Nedim Paşa wanted to buy her

95 One zirâ‘ equals $0,57417 \mathrm{~m}^{2}$ and $75,8 \mathrm{~m}$. 
shop but because she did not sell it, he was utterly "offended" (münfacil) and clearly held a veritable grudge against her. As a consequence, he first had her shop pulled down "by provoking the Imperial Shipyard"96 on the basis of a "rumor" (şâyia) that the building of the shop was "supposedly contrary to the harbor regulation." ${ }^{\prime 97}$ Habibe Hanım added, however, that this was not enough for Mahmud Nedim Paşa. He also halted the reconstruction of her new shop even after she gained permission from the Building Administration. But on what basis could he do that given the fact that he was the owner of the tobacco shop next to hers, as well as a two-story coffee house built in a similar manner upon the same type of piling on precisely the same quay? Moreover, there were other shops built in similar ways. She pointed at, as an example, the big "gazino" at the Fener coast owned by İsmail Paşa, the governor of İzmit at the time, which was likewise constructed over the sea. She also mentioned the houses on the shore from Eyüb all the way to the lemon wharf as well as 40-50 other similar shops near hers. Among "all these visible examples," only her grocery store, she argued, became the target of Mahmud Nedim Paşa's "spitefulness" (nefsâniyet). ${ }^{98}$ By all means, she considered this "unjust treatment" (mağdûriyet) unacceptable in the "age of justice and equity" in which she was supposed to be living. ${ }^{99}$ She demanded that the case be referred to the Supreme Council.

The discussions that transpired as a result of Habibe Hanım's last petition hinged on the serious objections which she daringly raised. Her petition stirred up another investigation process concerning the other shops built on pilings extending from the land out over the sea which were found to be equally deleterious to the operations of the wharf and ferry quay. Obviously, they also had to be demolished in a manner consistent with the idea of "justice and equity." Hence, the questions had to be answered collectively: the number of shops and their date of construction, the institutions which authorized them, and whether the owners possessed proper documents that authorized the construction of their properties.

Unfortunately, we do not have documentation answering these inquiries. But two points are nevertheless clear. One is that they found three to four shops around the quay which needed to be removed. Another is that Mahmud Nedim Paşa indeed had a two-story coffee house and a tobacco shop in the area precisely as claimed by Habibe Hanım. However, when Server Efendi

\footnotetext{
96 “Tersâne-i 'Âmire'yi tahrîk ile”: воA, A.\}мкт.мнм, 431/64.

97 "gûyâ lîmân nizâmına mugâyir olduğu": BOA, A.\}M KT.MHM, 431/64.

98 "bunca emsâli meydânda iken": BOA, A.\}мКт.мнм, 431/64.

99 воА, А.\}мкт.мнм, 431/64.
} 
wrote to him to inquire about the nature of these properties, he replied that he only had "a coffee house in the form of a [ferry] station for passengers." $100 \mathrm{He}$ did not mention the tobacco shop. Furthermore, as the investigation revealed, the coffee house and the tobacco shop were built by turning the covered waiting lounge constructed "for passengers and officials to protect them from the rain" into a new form. ${ }^{101}$ Therefore, the ferry station was already there before Mahmud Nedim Paşa converted it into a shop. We also learn that some tradesmen of lemon, grain, and dried fruits presented a petition asking for the removal of these shops.

In the final decision, all these shops including those possessed by Mahmud Nedim Paşa and Habibe Hanım were to be pulled down and the owners were to be reimbursed only if they produced the proper title deeds. This result must not have been ideal for Habibe Hanım. Even though it might have given her a sense of justice and equity since Mahmud Nedim Paşa's shops were also included in the decision for the demolition, she was faced with the unpleasant reality of undervaluation. The fact that she was granted extra 3,000 piasters as an act of "imperial benevolence"102 to compensate the "misery" (sefâlet) that she went through during the proceedings was most probably not enough, given her claim that one zirấ of her land was worth around 1,0oo piasters whereas she was only given $65^{\circ}$ piasters per zirâc. Mahmud Nedim Paşa, on the other hand, was adept and powerful enough to use his connections to ensure, in the end, that he could annex Habibe Hanım's shop. Yet, he became a victim of his own malevolence and Habibe Hanım succeeded in reversing his schemes against him.

Altogether, is the case of Habibe Hanım an example of "speak[ing] Tanzimat" as defined by Petrov? ${ }^{103}$ Was she an "ordinary" subject who "learned" how to "speak Tanzimat"? 104 Even though it is questionable how "ordinary" she was as a property owning actor in a very commercial and lucrative area of the city, her employment of the concept of "asr-ı ma'delet" (the age of justice and equity) seems to confirm the fact that historical persons used "the key elements of the

\footnotetext{
100 "müşterîlere mevkif kılıklu kahve dükkânı": вOA, A.\}м Кт.мнм, 431/64.

101 "me'mûrlar ile müşterîlerin yağmurdan muhâfazası zımnında": воА, А.\}мкт.мнм, $431 / 64$.

102 "sadaka-yı seniyye": воА, А.\}мкт.мнм, 431/64.

103 Milen V. Petrov, "Everyday Forms of Compliance: Subaltern Commentaries on Ottoman Reform, 1864-1868," Comparative Studies in Society and History 46, no. 4 (October 2004): 733 .

104 Ibid.
} 
language of the Tanzimat reforms" to their benefit as mentioned by Petrov. ${ }^{105}$ However, without a deeper engagement in conceptual history, it would be misleading to confine the term ma'delet to "the language of the Tanzimat reforms." It is an open question: How different would the language be had she "spoken" in previous periods? In addition, Habibe Hanım's case challenges any tendency of Ottoman historians to see the concept of equality only in religious and ethnic terms since her example cuts through the idea of equality in terms of class and social status.

\section{Conclusion}

When E. P. Thompson conceived the term "moral economy," he did not think of corruption as one of its defining elements as J. P. Olivier de Sardan later did in an African context. ${ }^{106}$ The association of moral economy with any form of corruption is "surprising," Sardan states, because corruption has been "unanimously stigmatized as amoral or immoral."107 However, as "seen from the actors' point of view," he argues, corruption is not necessarily to be morally condemned but also socially legitimized. ${ }^{108}$ It is of course hard to disagree with him if we confine "the actors" to those who benefit from corruption in one way or another. Nevertheless, the processes in which corruption is legitimized constitute an angle from which one can see corruption as a part of a moral economy. Throughout this essay, I have presented a different angle: the concept of honor as employed by both real estate owners and state institutions against corruption was not only a moral but also an economic theme that revolved around the question of locational values in an environment in which the rent market was in a constant state of change due to planning activities in the city. The concept of honor was the binding element of the collective fiction of urban rent that the government tried to communicate through different layers of society.

I have introduced the cases of Gülizar Hanım and Habibe Hanım in order to demonstrate how city dwellers developed narrative and legal strategies in the

\footnotetext{
105 Ibid., 743 .

106 E. P. Thompson, "The Moral Economy of the English Crowd in the Eighteenth Century," Past \& Present, no. 50 (February 1971); Olivier de Sardan, "A Moral Economy of Corruption in Africa?."

107 Olivier de Sardan, “A Moral Economy of Corruption in Africa?," 25.

108 Ibid.
} 
face of adversity which they experienced. Gülizar and Habibe Hanim, who are rather invisible actors in mainstream historiography as women, were nonetheless quite capable of building discourses of morality and legality into urban politics and administration. They fiercely negotiated their understanding of justice against corruption. However, these negotiations were not only legal but also moral and emotional. More importantly, they were also commodified in an economy of corruption. As the block system emerged as the dominant form of urban typology, the streets gained new commodified margins as the space where the rent market was restructured for the creation and recreation of new use and exchange values in the built environment. The question of what determines property values was at the basis of many conflicts during this intense period of spatial restructuring and value took on a social character as a struggle over şeref.

These women's cases also reveal how the discourses of modernity, state legitimacy, and justice were localized as tangible practices on the ground. Local, fluid, and contingent articulations of urban tanzîmât as seen in the examples of two female property owners were more contentious and less "modern" and coherent than we tend to think. The way in which the state and justice became localized was fluid and open to everyone's bid in the making. The legal mechanisms, such as petitioning which the government made available to city dwellers, also underline how the state's surveillance instruments were inclusive and tried to co-opt subjects when fighting against corruption. This, furthermore, shows how the state shared responsibilities of defining and controlling official transgressions with its subjects as property owners were made into agents who monitored the activities of the urban personnel during the reorganization activities.

\section{Author Bio}

Eda Güçlü is a PhD candidate at Central European University (CEU), Department of History, Budapest. Her dissertation focuses on the social practices of property in nineteenth-century Istanbul and examines how property mediated personal, communal, and state-society relations in the process of urban planning and spatio-temporal restructuring that the Ottoman capital went through in this period. She received her MA from Sabancı University, Department of History, Istanbul, with a thesis on the transformation of waqf property in the nineteenth century. She is currently teaching at Central European University as one of the instructors of the Source Language Teaching Group. 


\section{Bibliography}

\section{Primary Sources}

Başbakanlık Osmanlı Arşivi (B OA), İstanbul

İrade-i Dahiliye (í.DH)

İrade-i Meclis-i Vâlâ (ì.MVL)

İrade-i Meclis-i Mahsus (i.MMs)

Meclis-i Vâlâ (MVL)

Sadaret Evrakı: Mektubu Kalemi: Mühimme Kalemi Evrakı (A.\}м кт.мнм)

\section{Newspapers}

Takvîm-i Vekâyic

Tasvîr-i Efkâr

\section{References}

Abu-Manneh, Butrus. "The Sultan and the Bureaucracy: The Anti-Tanzimat Concepts of Grand Vizier Mahmud Nedim Paşa." International Journal of Middle East Studies 22, no. 3 (August 1990): 257-74.

Baruh, Lorans Izabel. “The Transformation of the 'Modern' Axis of Nineteenth-Century Istanbul: Property, Investments and Elites from Taksim Square to Sirkeci Station." PhD Dissertation, Boğaziçi University, 2009.

Behar, Cem. A Neighborhood in Ottoman Istanbul: Fruit Vendors and Civil Servant in the Kasap Ilyas Mahalle. Albany: State University of New York Press, 2003.

Bloch, Ernst. Heritage of Our Times. Cambridge: Polity Press, 1991.

Can, Selman. "Osmanlı Mimarlık Teşkilatının XIX. Yüzyıldaki Değişim Süreci ve Eserleri ile Mimar Seyyid Abdülhalim Efendi.” PhD Dissertation, Istanbul University, 2002.

Çelik, Zeynep. The Remaking of Istanbul: Portrait of an Ottoman City in the Nineteenth Century. Berkeley: University of California Press, 1993.

Cerasi, Maurice. The Istanbul Divanyolu. Istanbul: Orient-Institut, 2004.

Ergin, Osman Nuri. Mecelle-i Umûr-ı Belediyye Vol. 3 and Vol. 4. Istanbul: İstanbul Büyükşehir Belediyesi Kültür İşleri Daire Başkanlığı Yayınları, 1995.

Gül, Murat. The Emergence of Modern Istanbul: Transformation and Modernization of a City. London: Ів Tauris, 2009.

Gül, Murat and Richard Lamb. "Mapping, Regularizing, and Modernizing Ottoman Istanbul: Aspects of the Genesis of the 1839 Development Policy." Urban History 31, no. 3 (2004): 420-36.

Harootunian, Harry. History's Disquiet: Modernity, Cultural Practice, and the Question of Everyday Life. New York: Columbia University Press, 2000. 
Harootunian, Harry. "Some Thoughts on Comparability and the Space-Time Problem.” Boundary 2 32, no. 2 (Summer 2005): 23-52.

Hill, Lisa. "Adam Smith and the Theme of Corruption." The Review of Politics 68 (2006): 636-62.

İnal, İbnülemin Mahmud Kemal. Osmanlı Devrinde Son Sadrazamlar Vol. 1. İstanbul: Dergah Yayınları, 1982.

Kaya, Alp Yücel and Yücel Terzibaşoğlu. “Tahrir'den Kadastro'ya: 1874 İstanbul Emlak Tahriri ve Vergisi: 'Kadastro tabir olunur tahrir-i emlak.'” Tarih ve Toplum Yeni Yaklaşımlar 9 (2009): 9-58.

Kılınçoğlu, Deniz T. Economics and Capitalism in the Ottoman Empire. London, New York: Routledge, 2015 .

Kırlı, Cengiz. "Yolsuzluğun İcadı: 1840 Ceza Kanunu, İktidar ve Bürokrasi." Tarih ve Toplum Yeni Yaklaşımlar, no. 3 (Fall 2006): 45-118.

Künnecke, Martina. Tradition and Change in Administrative Law: An Anglo-German Comparison. Berlin, New York: Springer, 2007.

Lévy-Aksu, Noémi. "Building Professional and Political Communities: The Value of Honor in the Self-Representation of Ottoman Police during the Second Constitutional Period." European Journal of Turkish Studies 18 (2014):1-18.

Malfroy, Sylvain. "The Modern Completion of the Nineteenth-Century Fabric Based on the Grid and Blocks." In Rethinking the XIXth Century City, edited by Attilio Petruccioli, 141-9. Cambridge, Massachusetts, The Aga Khan Program for Islamic Architecture, 1998.

Neumann, Christoph K. "Marjinal Modernitenin Çatışma Mekanı Olarak Altıncı Daire-i Belediye." In 6. Daire, İlk Belediye 1857-1913: Beyoğlu'nda İdare, Toplum, Kentlilik Sergi Kataloğu, prepared by Beyoğlu Belediyesi and İstanbul Bilgi Üniversitesi Toplum, Ekonomi, Siyaset Araştırma Merkezi (TESAR) Yerel Yönetimler Araştırma Birimi, İstanbul, 2004. Exhibition catalog.

Nye, J. S. "Corruption and Political Development: A Cost-Benefit Analysis." The American Political Science Review 61, no. 2 (June 1967): 417-27.

Olivier de Sardan, J. P. “A Moral Economy of Corruption in Africa?” The Journal of Modern African Studies 37, issue 1 (March 1999): 25-52.

Oktay, Tarkan. Şehremaneti, Osmanlıda Büyükşehir Belediye Yönetimi. İstanbul: Yeditepe Yayınevi, 2011.

Öncel, Ayşe Derin. Apartman: Galata'da Yeni bir Konut Tipi. Istanbul: Kitapyayınevi, 2010. Parmaksızoğlu, Duygu. "Evden Emlağa Fikirtepe: Rant ve Spekülasyon Ekseninde Kentsel Dönüşüm.” 28 September 2014. http://www.jadaliyya.com/pages/ index/19382/evden-emlaga-fikirtepe_rant-ve-spekulasyon-eksenin. [The English version: "From Home to Real Estate: Urban Redevelopment on the Axis of Speculation in Istanbul." 6 October 2014. http://www.jadaliyya.com/pages/ index/19508/from-home-to-real-estate_urban-redevelopment-on-th]. 
Parsons, Deborah L. "Paris is not Rome, or Madrid: Locating the City of Modernity." Critical Quarterly 44, no. 2 (July 2002): 17-29.

Petrov, Milen V. "Everyday Forms of Compliance: Subaltern Commentaries on Ottoman Reform, 1864-1868." Comparative Studies in Society and History 46, no. 4 (October 2004): $730-59$.

Pierce, Leslie. "Seniority, Sexuality, and Social Order: The Vocabulary of Gender in Early Modern Ottoman Society." In Women in the Ottoman Empire: Middle East Women in the Early Modern Era, edited by Madeline C. Zilfi, 169-96. Leiden, New York, Köln: Brill, 1997.

Pierce, Steven. "Looking Like a State: Colonialism and the Discourse of Corruption in Northern Nigeria." Comparative Studies in Society and History 48, no. 4 (October 2006): 887-914.

Pinon, Pierre. "The Parcelled City: Istanbul in the 19th Century." In Rethinking the XIXth Century City, edited by Attilio Petruccioli, 45-64. Cambridge, Massachusetts, The Aga Khan Program for Islamic Architecture, 1998.

Prasad, Ritika. “Time-Sense': Railways and Temporality in Colonial India." Modern Asian Studies 47, no. 4 (July 2013): 1252-82.

Rosenthal, Steven. "Foreigners and Municipal Reform in Istanbul: 1855-1865." International Journal of Middle East Studies 11, no. 2 (1980): 227-45.

Rubin, Avi. Ottoman Nizamiye Courts: Law and Modernity. New York: Palgrave Macmillan, 2011.

Saraçoğlu, Mehmet Safa. "Letters from Vidin: A Study of Ottoman Governmentality and Politics of Local Administration, 1874-1877." PhD Dissertation, Ohio State University, 2007.

Schiller, Russell. The Dynamics of Property Location: Value and the factors which drive the location of shops, offices and other land uses. London, New York: Spon Press, 2001.

Scott, James C. "The Analysis of Corruption in Developing Nations." Comparative Studies in Society and History 11, no. 3 (June 1969): 315-41.

Selman, Gül Güleryüz. "Urban Development Laws and Their Impact on the Ottoman Cities in the Second Half of the Nineteenth Century." ma Thesis, Middle East Technical University, 1982.

Sûdî, Süleyman. Osmanlı Vergi Düzeni (Defter-i Muktesid). Edited by Mehmet Ali Ünal. Isparta, 1996.

Tekdemir, Aziz. “Ticaret Nezareti (1839-1876).” PhD Dissertation, Istanbul University, 2010.

Thompson, E. P. "The Moral Economy of the English Crowd in the Eighteenth Century." Past \& Present, no. $5^{\circ}$ (February 1971): 76-136.

Zandi-Sayek, Sibel. "Public Space and Urban Citizens: Ottoman Izmir in the Remaking, 1840-189o." PhD Dissertation, University of California, 2001. 